\title{
SOCIO-ECONOMIC AND SPATIAL CORRELATIONS OF THE EASTERN EUROPEAN HEALTH PARADOX IN HUNGARY
}

\section{A KELET-EURÓPAI EGÉSZSÉGPARADOXON TÁRSADALMI- GAZDASÁGI ÉS TERÜLETI ÖSSZEFÜGGÉSEI MAGYARORSZÁGON}

\author{
Zoltán EGRI ${ }^{\mathrm{a}}$, Tamás TANCZÓS ${ }^{\mathrm{b}}$ \\ ${ }^{a}$ Szent Istvan Egyetem Gazdasági, Agrár- és Egészségtudományi Kar Tessedik Campus, Address: 5540 \\ Szarvas, Szabadság u. 1-3, phone: +3666313311, e-mail: egrized@gmail.com \\ ${ }^{\mathrm{b}}$ Eszterházy Károly Főiskola Gazdaság- és Társadalomtudományi Kar, Address: 3300 Eger, Egészségház \\ utca 4, phone: +3636520473, e-mail: kistancos@ektf.hu
}

Cite this article: Egri, Z., Tanczós, T. (2015). Socio-economic and spatial correlations of the Eastern European health paradox in Hungary. Deturope, 7, 2: 138-156

\begin{abstract}
This paper describes the Hungarian aspects and the latest results of the so-called Eastern European health paradox in terms of (micro-)regions. In particular, this paper aims at highlighting the spatial correlations of premature mortality and the main causes of death by gender as well as their socio-economic and spatial embeddedness. The tool for our study is represented by exploratory spatial data analysis (ESDA): the main health inequalities of Hungary's micro-regions are described with the use of global autocorrelation tests as well as regression models suitable for the identification of general and spatial features.

According to our findings, the causes of premature death are characterised by a marked spatial determination for both genders but mostly for men. The regression models of the causes of premature death have confirmed that neighbourhood relations and micro-regional inequalities in issues like the level of socio-economic development, settlement structure, lifestyle, social capital, healthcare infrastructure or social deprivation have substantial impacts on mortality in a given area in the case of men. These findings are also true for women, except for one issue: neighbourhood assimilation. It should be noted in view of our research findings that, in addition to socio-economic explanatory factors, spatiality (belonging to a region) is a major explanatory factor regarding the micro-regional inequalities of premature mortality. In particular, Borsod-Abaúj-Zemplén county, known as a former industrial base, should be noted here; this county is a significant and complex crisis area with regard to the health status of both genders in Hungary today. As a short-term measure for the improvement of spatial health status, the development of health awareness and the mitigation of psychosocial stress (by civil organisations) are suggested.
\end{abstract}

Keywords: health inequalities, health paradox, spatial autocorrelation, premature mortality, spatial regression analysis

\begin{abstract}
Absztrakt:
Dolgozatunk az ún. kelet-európai egészségparadoxon magyarországi vonatkozásait, legújabb eredményeit ismerteti (kis-)térségi megközelítésben. Tanulmányunkban arra vállalkoztunk, hogy bemutassuk a nemenkénti korai halandóság és a föbb halálokok térbeli összefüggéseit, valamint azok társadalmigazdasági és területi beágyazottságát. Vizsgálataink eszköztárát a területi adatok feltáró módszere (ESDA) jelenti: a globális autokorrelációs teszt, valamint az általános és a térbeli jegyeket is tükröző regressziós modellek segítségével mutatjuk be Magyarország kistérségeinek föbb egészségegyenlötlenségeit.

Megállapítást nyert, hogy hangsúlyos térbeli determináció jellemzi az idő előtti halálokokat mindkét nem esetében, de különösen a férfiak tekintetében. A korai halálokok regressziós modelljei igazolták, hogy a társadalmi-gazdasági fejlettség, a településszerkezet, az életmód, a társadalmi tőke, az egészségügyi infrastruktúra, a kirekesztés kistérségi egyenlötlenségei, valamint a szomszédsági relációk alapvetően
\end{abstract}


befolyásolják a területi halandósági állapotot a férfiak esetében. A női korai halandóság esetében is igazak ezek a megállapítások, egyetlen kivétellel: ez pedig a szomszédsági hasonulás. Kutatási eredményeink alapján fontos kiemelnünk, hogy a társadalmi-gazdasági és egyéb magyarázó faktorokon túl a térbeliség, a térséghez tartozás fontos magyarázó faktor az idő előtti halálozás kistérségi egyenlőtlenségében. Különösen a korábbi ipari bázist, Borsod-Abaúj-Zemplén megyét szükséges megemlíteni, amely igen szignifikáns komplex válsággócnak számít mindkét nem egészségi állapotában napjaink Magyarországán. A területi egészségi állapot javítása érdekében rövid távon az egészségmagatartás fejlesztését és a pszichoszociális stressz (civil szervezetek általi) oldását javasoljuk.

Kulcsszavak: egészségegyenlőtlenségek, egészségparadoxon, területi autokorreláció, idő elötti halandóság, térbeli regresszió elemzés

\section{INTRODUCTION}

Nations on the eastern and western side of the Iron Curtain - created after World War II and viewed as the political metaphor of a divided Europe - established their own socio-economic systems. The line dividing the two blocks also led to the emergence of an epidemiological (Boncz-Sebestyén, 2006) (or healthcare) iron curtain (EC, 2008), the eastern side of which was characterised by a specific phenomenon i.e. the so-called health paradox. This paradox means that there is a strikingly high rate of premature mortality in the transforming societies and that this region shows a much worse general health status than the one that would be justified on the basis of economic indicators. (Kopp-Skrabski, 2001)

The features and characteristics of the health paradox can be summarised as follows:

- While life expectancy at birth was similar in the two blocks up until the 1960s, the socialist block has been struggling with stagnation and reduction since 1965.

- Different mortality trends can be seen even within the socialist block.

- This issue affects most of all the economically active age groups including, in particular, men.

- The main factor in the eastern epidemiological crisis is the "missed cardiovascular revolution", though mortality attributable to cancer and "man-made" (external) causes of death is also high.

- This phenomenon emerged during peacetime in a period with no known cases of global/regional infection and famine or any natural disaster.

- Prior to the socio-economic changes, Hungary was among the countries with the worst mortality status and trends, though Russia, the Ukraine and the Baltic states were hit by a deeper crisis.

- The transformation (or adaptation) crisis further deteriorated the already ailing health situation. 
- Stress (as the invisible hand) as well as psychiatric and behavioural factors also play a major role in premature death rates.

- Focusing on Hungary within the Central and Eastern European region, it can be stated that the country is still in a disadvantageous situation in terms of the main health parameters and that the high rate of premature mortality represents a serious public health problem both for men and women. (Cornia-Paniccia, 2000; Weidner-Cain, 2003; Daróczi, 2004; Meslé, 2004; Kopp et al., 2007)

\section{OBJECTIVES AND METHODS}

As the various sources of literature discussing the Eastern European health paradox deal with this issue mainly at national level, our study focuses on spatial inequalities and the inequalities of premature mortality. The socio-economic and spatial inequalities (of,) and the main correlations regarding, public health status in Hungary have already been described in many studies. (Klinger, 2006; Hablicsek-Kovács, 2007; Daróczi, 2004; Csite-Németh, 2007; Skrabski, 2003; Bálint, 2010; Uzzoli, 2008; Vitray, 2011; Szilágyi-Uzzoli, 2013.) At the level of micro-regions, allowing for more complex analyses, life expectancy at birth represents the main focus of study, whereas the number of research projects dealing with the various causes of death is not high in general. It is clear from the foregoing that premature mortality still represents a major public health issue in Hungary. Therefore, we have decided to utilise (at least partly) this niche and to analyse the phenomenon of (micro-)regional premature mortality. We have also decided to launch a complex study of the other niche area i.e. the causes of premature death in micro-regions. The paper wants to find answers to the following questions.

- What spatial correlations can be discovered from the health status by gender?

- What are the impacts of micro-regional inequalities in issues like the level of socioeconomic development, settlement structure, spatiality, health awareness, social capital, health infrastructure, segregation and social deprivation on the main causes of death and premature mortality?

- What are the correlations for the male and female population?

- How do contiguity relations influence the spatiality of the various causes of death? 
We have decided to use standardised mortality ratio (SMR) by gender and, in particular, its early (0-64 years) version. ${ }^{42}$ The analyses included - in addition to the SMR of all premature deaths - the main causes of premature death by gender: infectious and parasitic diseases, malignant neoplasms, mental and behavioural disorders, diseases of the respiratory system, diseases of the circulatory system, diseases of the digestive system, external causes of morbidity and mortality, preventable diseases, and diseases attributable to smoking. Furthermore, the values of life expectancy at birth by gender were also involved in the analyses.

Since ancient times numerous theories have been devised for the explanation of health inequalities. (Andorka, 2006; Whitehead, 1997; Mackenbach, 2006; Omran, 1971; Preston, 1975; Wilkinson-Marmot, 2003; WHO, 2008; Kopp-Skrabski, 2001; Marmot, 2004; Black, 1980.) Most theories agree in the notion that social and economic inequalities act as direct and indirect harm to the health condition of individuals. (Villermé, n.d., Wirchow, n.d. see Mackenbach, 2006) These findings have been confirmed also in terms of spatiality. (Queste et al., 2002; Groenewegen et al., 2003; Mackenbach et al., 1991; Mackenbach-Looman, 1994; Gutiérrez-Fisac, 2000; Leyland, 2004; Woods et al., 2005; Bálint, 2010; Uzzoli, 2013.)

This paper examines spatial inequalities on the basis of the relevant health inequalities literature and in view of the following factor groups and indicators.

- Level of socio-economic development: percentage of individuals with higher education qualifications (by gender), illiteracy rate (by gender), unemployment rate (by gender), percentage of taxpayers, Robin Hood index, percentage of car owners, personal income tax base per capita, percentage of aid beneficiaries.

- Settlement structure and infrastructure: population density, settlement density, urban/rural ratio, percentage of largest settlement inhabitants, cities with county rights.

- Health awareness and health culture: causes of death attributable to smoking (SMR), chronic liver diseases and cirrhosis SMR ( as alcohol consumption proxy), difference between male and female life expectancy at birth, extent of hidden economy.

- Social capital: number of registered criminals per 10000 persons, number of divorces per 100 marriages, number of non-profit organisations per 100 persons.

- Healthcare infrastructure: number of hospital beds per 1000 persons, number of family doctors per 10000 persons, infant mortality rate.

\footnotetext{
${ }^{42}$ SMR refers to a mortality rate that could be observed in the study region if the composition of the population by age and gender would be the same as that of the standard population i.e. in this case the population of Hungary in 2005.
} 
- Segregation and social deprivation: percentage of Roma population, percentage of endangered minors.

- Spatiality, contiguity: dummy variables for counties and regions, and spatial weights matrixes. (See below, regression models.)

Observation period: 2009-2011. The observation period was chosen to include the period of the national census (2011) given that many of the major indicators (e.g. information on the level of education or ethnic minorities) are assessed or reported only during this period.

Observation unit: micro-region (174). ${ }^{43}$ As spatiality (belonging to a region) is considered as a relevant influencing factor, it is important to show not only the micro-regions but also the counties and regions of Hungary (Fig. 1).

Figure 1 The micro-regions, the counties and the NUTS 2 regions in Hungary

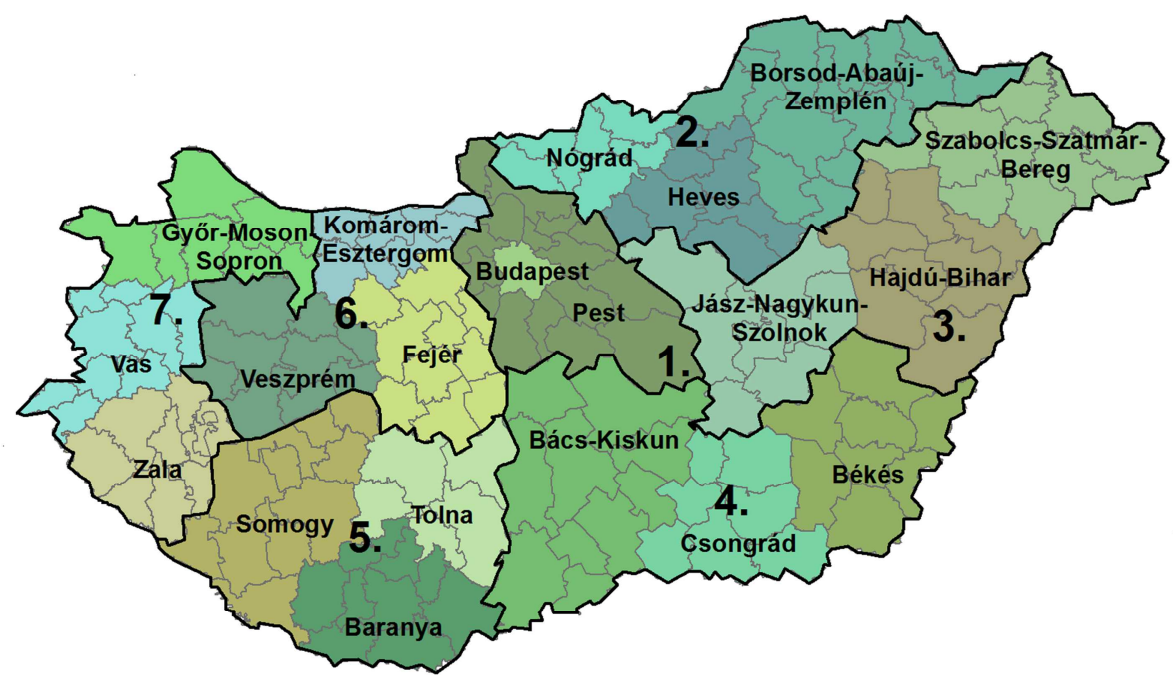

Key:

Heves - County (NUTS3)

1. - Central Hungary 2. - North Hungary 3. - North Great Plain 4. - South Great Plain 5. - South Transdanubia 6. - Middle Transdanubia 7. - West Transdanubia (NUTS2 regions)

Source: own computing and editing

Data sources: National Land Development and Land Management Information System (TeiR), Regional Database, Central Statistical Office (KSH), HCCI Institute for Economic

\footnotetext{
${ }^{43}$ As of 1 January 2013, micro-regions were replaced by districts, which are defined as administrative and spatial policy divisions at local (city and agglomeration) level. As our research work (including this study) covers a long period, we have chosen to use the level of micro-regions in order to benefit from the availability of the relevant statistical data.
} 
and Enterprise Research (GVI), National Institute for Health Development (OEFI) online databases and publications.

The explanatory spatial data analysis (ESDA) was the data processing method used for finding the answers to the abovementioned questions. See Anselin (2005), Bálint (2010) for more details. GeoDa 1.6.0 was used to perform the analyses.

Global autocorrelation analysis with Moran's I was used to find the answer to the first study question. According to Tóth (2003), “Moran's I is an indicator showing the similarity or difference of the observed area compared to its neighbour." (Tóth, 2003, p. 42. See Anselin, 2005 for description of method.) Regression models were used to demonstrate the main spatial and socio-economic correlations of premature mortality. The main premature mortality indicators were used as dependent variables and the above indicators were treated as independent variables. Ordinary least squares method (OLS), and the maximum likelihood (ML) estimation of two regression models i.e. SLM (Spatial Lag Model) and SEM (Spatial Error Model) were used to find the answers to the questions. (Anselin, 2005; Nemes Nagy, 2009.) As the regression technique is fairly sensitive to multicollinearity, data compression was also carried out through a factor analysis with SPSS for Windows 20.0.

\section{RESULTS}

\section{Spatial autocorrelation analyses}

The first part of this chapter shows the mapping of the global spatial patterns of the various mortality rates and health variables by gender. Various spatial weights matrices were created in order to show the most favourable neighbourhood (autocorrelation) relations. The following neighbourhood matrices were used: queen, rook, 2, 4, 6, 8, 10, 12 and 15 nearest neighbours. Table 1 contains the global spatial autocorrelation index (Moran's I) completed with the corresponding spatial weights matrices.

The main causes of death appearing /involved in the study are characterised by positive spatial autocorrelation, with one exception. It means that it is possible to ignore the null hypothesis, according to which there is no neighbourhood assimilation regarding/in the case of the individual causes of death. Spatial homogeneity is highest for crude mortality rates and lowest in the case of infectious and parasitic SMR; these correlations are true for both genders. Furthermore, Table 1 shows that, sometimes, the best mortality spatial structure of each gender can be described with different neighbourhood relations e.g. the highest Moran's 
I is given by the 2 nearest neighbours for men and by the 12 nearest neighbours for women in the SMR of mental and behavioural disorders.

Male mortality is coupled with higher spatial autocorrelation, mostly for life expectancy at birth and in terms of SMR for diseases of the circulatory system, diseases of the respiratory system and all premature deaths. Female premature mortality shows a regionalisation mostly along the diseases of the circulatory system, attributable to smoking, preventable and all deaths as well as life expectancy at birth. In general, however, there is not a very high level of neighbourhood assimilation (Moran's I for per capita income: 0.52); today's Hungary shows a substantial regionalisation along the causes of premature death and other health variables.

Table 2 Spatial autocorrelation of health variables with Moran's I (2009-2011)

\begin{tabular}{|l|c|c|}
\hline Main health variables & $\begin{array}{c}\text { Moran's I } \\
\text { (men) }\end{array}$ & $\begin{array}{c}\text { Moran's I } \\
\text { (women) }\end{array}$ \\
\hline All premature deaths & $0.296^{(4 \mathrm{n})}$ & $0.224^{(2 \mathrm{n})}$ \\
\hline Crude death rate & $0.435^{(2 \mathrm{n})}$ & $0.402^{(2 \mathrm{n})}$ \\
\hline Life expectancy at birth & $0.356^{(2 \mathrm{n})}$ & $0.258^{(2 \mathrm{n})}$ \\
\hline Difference in life expectancy at birth & \multicolumn{2}{|c|}{$0.245^{(2 \mathrm{n})}$} \\
\hline Infectious and parasitic diseases & $0.078^{(8 \mathrm{n})}$ & $-0.018^{(15 \mathrm{n})}$ \\
\hline Malignant neoplasms & $0.246^{(2 \mathrm{n})}$ & $0.121^{(2 \mathrm{n})}$ \\
\hline Mental and behavioural disorders & $0.285^{(2 \mathrm{n})}$ & $0.021^{(12 \mathrm{n})}$ \\
\hline Diseases of the respiratory system & $0.313^{(\mathrm{q})}$ & $0.156^{(\mathrm{ro})}$ \\
\hline Chronic lower respiratory diseases & $0.318^{(2 \mathrm{n})}$ & $0.173^{(6 \mathrm{n})}$ \\
\hline Diseases of the circulatory system & $0.357^{(\mathrm{ro})}$ & $0.256^{(2 \mathrm{n})}$ \\
\hline Diseases of the digestive system & $0.214^{(2 \mathrm{n})}$ & $0.188^{(2 \mathrm{n})}$ \\
\hline Chronic liver diseases and cirrhosis & $0.259^{(2 \mathrm{n})}$ & $0.216^{(2 \mathrm{n})}$ \\
\hline External causes of morbidity and mortality & $0.225^{(2 \mathrm{n})}$ & $0.142^{(4 \mathrm{n})}$ \\
\hline Preventable & $0.268^{(2 \mathrm{n})}$ & $0.237^{(\mathrm{q})}$ \\
\hline Attributable to smoking & $0.196^{(2 \mathrm{n})}$ & $0.249^{(2 \mathrm{n})}$ \\
\hline Infant mortality & \multicolumn{2}{|c|}{$0.167^{(\mathrm{q})}$} \\
\hline
\end{tabular}

Source: own computing and editing

\section{Regression results}

This chapter describes the models that influence and explain the spatial inequalities of premature mortality and the main causes of death at the level of micro-regions.

Based on the processed volume of domestic and foreign studies, the following hypotheses are made:

- Level of socio-economic development: it is assumed that a better trained population is more productive and enjoys a better labour market and income position; therefore, it has better chances to avoid premature death. ${ }^{45}$

\footnotetext{
${ }^{44}$ The abbreviation of the best weights matrix is put in brackets near Moran's I. "q" means queen, while "ro" means rook as a neighbour. " $\mathrm{n}$ " and the number before it mean the number of the nearest neighbours (e.g. " $2 \mathrm{n}$ " means the two nearest neighbours).
} 
- Settlement structure and infrastructure: it is assumed that the person living at a higher level of the settlement hierarchy (which can be measured only indirectly) and the regions with better infrastructure have better life chances. ${ }^{46}$

- Spatiality, contiguity: on one hand, this assumption expresses the notion of "belonging to somewhere". As seen before, certain causes of death are concentrated in space and, therefore, spatiality may be considered as an independent explanatory factor. The study aims at identifying the regions described as crisis areas in terms of mortality. In general, crisis areas and their components (symptoms and causes) form a complex stochastic system (Bakos, 2003). Therefore it is thought that these can be identified in the relevant space, even apart from the inequalities of the socio-economic environment. On the other hand, this paper wants to prove neighbourhood relations as well.

- Health awareness and health culture: the lower the number and extent of healthimpairing behaviours at the level of micro-regions, or the lower the share of hidden economy, the better the life-chances.

- Social capital: premature mortality decreases when there is a rise in social activities and relations or a reduction in criminal rate in the relevant region.

- Healthcare infrastructure: better mortality rates can be expected in (or near) regions where adequate health services are available.

- Segregation and social deprivation: the higher the percentage of Roma population and endangered children, the higher the occurrence of premature deaths.

We are aware of the fact that the momentary values of the variables involved (even if they represent multiannual averages) cannot fully explain the micro-regional inequalities regarding health status and the main causes of death in the study period. On the one hand, e.g. the presence over long years or decades of a poor socio-economic situation and the related depression syndrome (Kopp-Skrabski, 2001) and stress may not be measured directly. (This is the reason for using dummy variables.) In addition/Furthermore, it should be noted that the relevant indicators have both direct impacts and indirect impacts (through several factors) on life expectancy. (Daróczi, 2004) On the other hand, the ecological analyses and the

\footnotetext{
${ }^{45}$ As stated above, the regression technique is fairly sensitive to multicollinearity. For this reason we applied factor analysis to compress the socio-economic indicators by gender. As a result, we obtained, for each gender, a development factor that contains all relevant indicators. Each factor meets the applicable statistical requirements (KMO: 0.896 and 0.901; eigenvalue: 5.806 and 6.127; retained variance: 64.5-68.1).

${ }^{46}$ Just like in the case of socio-economic factors, a so-called settlement structure factor has been created with the use of indicators described above. Retained variance: approx. 70\%, eigenvalue: 3.332, KMO: 0.809.
} 
consolidation of individual data may lead to disinformation, mostly if these are interpreted at different territorial levels. (Ecological fallacy, see the relevant health-specific results e.g. Borrel - Arias, 1995; Fiscella-Franks, 1997.)

The results of those models are shown here which provide the most reliable correlations. ${ }^{47}$

\section{Results for male models}

As to all premature deaths of Hungarian men, the best matching model is obtained from the correlations among the level of development, settlement structure, smoking and the dummy variables of the crisis area (Borsod-Abaúj-Zemplén county, BAZ) ${ }^{48}$. (Tab. 2, "general" column.) The indicators involved are shown with their respective signs in the model: factors like the increase in the level of development and settlement structure (i.e. urban lifestyle), while smoking and living in BAZ county decrease life chances. Settlement structure becomes a significant explanatory factor when the model is controlled with the spatial dummy. (This step is thought to filter most of the outstanding figures and to confirm the crisis area nature of the county also in terms of mortality.)

Although the first model seems to serve the purpose of explanatory power and diagnostics better, we have created a new lifestyle model. (Tab. 2, "lifestyle" column.) The new model shows an overlap for smoking (as lifestyle factor) and for the crisis area. In addition, hidden economy and negative social circumstances (percentage of criminals) emerge as explanatory factors for higher premature mortality. The estimated indicator of black/underground/informal economy acts against human health as a result of such disadvantages "that can be felt on a wide scale ranging from the level of private individuals to that of society" (e.g. poor workplace conditions and work safety, etc., see Lackó et al., 2011, p. 3). The availability of hospital beds helps to improve mortality rates. In other words, premature mortality is higher in those Hungarian micro-regions where death rates attributable to smoking, the extent of black economy and the percentage of criminals are higher and where the number of hospital

\footnotetext{
${ }^{47}$ Based on Anselin, 2005, the spatial regressions were checked with the W (Wald test) $>$ LR (Likelihood ratio test) $>$ LM (Lagrange multiplier) formula. This relationship holds true for each model. As to OLS regression, the Jarque-Berra test was applied to see the normality of error terms, the Breusch-Pagan test was used to check for homoscedasticity, and Moran's I was taken to measure the spatial autocorrelation of the regression residuals. Multicollinearity was measured with MCN (Multicollinearity Condition Number). Information on the efficiency of the spatial models could be obtained by means of the pseudo $\mathrm{R}^{2}$ (or, in the case of OLS, adjusted $\mathrm{R}^{2}$ ), Akaike information criterion (AIC), log likelihood and Schwarz's Bayesian information criterion. (Anselin, 2005) Information from Lagrange multiplier is also given for each regression (regarding, of course, the OLS version).

${ }^{48}$ Borsod-Abaúj-Zemplén county (former heavy industry base) in North Hungary is one of the most backward counties. As far as regional development benefits are concerned, 13 and 10 of its 15 micro-regions are classified as less favoured areas and most disadvantaged areas (LHH) to be developed through multi-faceted adjustment programmes, respectively. (KSH, 2007) The population of the most disadvantaged micro-regions accounts for some $40 \%$ of the county population, which is one of the highest levels in Hungary.
} 
beds is lower. In fact, the micro-regions of BAZ county are above the average in terms of this latter indicator.

Table 3 shows the regression models of the main causes of death. In the premature mortality model of men attributable to diseases of the circulatory system ("circul") the significant explanatory factors include hidden economy, excessive workload, social capital (percentage of criminals), health-impairing behaviour, health infrastructure and spatiality. According to the findings of Kopp et al. (2007), excessive workload has a particular impact on male mortality caused by diseases of the cardiovascular system, which is properly explained by this equation. Among the health-impairing behaviours only the proxy related to smoking is involved, while the one related to alcohol consumption is not. The micro-regional differences of male circulatory mortality are also increased by the spatial inequalities of the crime rate. The premature mortality of men exceeds the average level of the territorial units that are characterised by a substantial presence of the informal economy and by a high rate of social deviance and a low level of health awareness. The BAZ dummy, seen in all deaths, appears again: mortality caused by diseases of the cardiovascular system is more probable in the micro-regions of BAZ county. Basic healthcare and lifestyle show a striking correlation in the model: although the number of family doctors is proportionately higher, it is not enough to eliminate the negative impacts of smoking.

Table 3 Premature mortality models of men

\begin{tabular}{|l|c|c|}
\hline & general & lifestyle \\
\hline constant & $\begin{array}{c}41.454^{*} \\
(22.64)\end{array}$ & $\begin{array}{c}26.329^{*} \\
(4.67)\end{array}$ \\
\hline development factor & $\begin{array}{c}-4.126^{*} \\
(-6.49)\end{array}$ & - \\
\hline \multirow{2}{*}{ settlement strucure } & $\begin{array}{c}-1.279^{* *} \\
(-2.49)\end{array}$ & - \\
\hline \multirow{2}{*}{ BAZ (dummy) } & $\begin{array}{c}5.886^{*} \\
(3.38)\end{array}$ & $\begin{array}{c}7.582^{*} \\
(4.40)\end{array}$ \\
\hline \multirow{2}{*}{ smoking } & $\begin{array}{c}0.934^{*} \\
(9.12)\end{array}$ & $\begin{array}{c}1.136^{*} \\
(11.10)\end{array}$ \\
\hline hidden economy & - & $32.759^{*}$ \\
& & $(4.27)$ \\
\hline
\end{tabular}

\begin{tabular}{|c|c|c|}
\hline & general & lifestyle \\
\hline criminal & 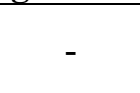 & $\begin{array}{c}0.041^{* *} \\
(2.49)\end{array}$ \\
\hline hospital bed & - & $\begin{array}{c}-0.207^{* *} \\
(-3.00)\end{array}$ \\
\hline lambda & $\begin{array}{l}0.318^{*} \\
(3.08)\end{array}$ & $\begin{array}{l}0.251^{*} \\
(2.32)\end{array}$ \\
\hline pseudo $\mathrm{R}^{2}$ & 0.747 & 0.711 \\
\hline AIC & 1051.4 & 1075.6 \\
\hline Log likelihood & -520.7 & -531.7 \\
\hline $\mathrm{SC}$ & 1067.2 & 1094.5 \\
\hline LM lag (OLS) & 0.21 & 1.21 \\
\hline LM error (OLS) & $3.95^{* *}$ & $3.87^{* *}$ \\
\hline
\end{tabular}

${ }^{*}$ At a significance level of $0.01,{ }^{* *}$ at a significance level of 0.05 .

See z-score values in brackets. The spatial weights matrix is based on rook neighbourhood.

Source: own computing and editing

Four factors influence the socio-economic inequalities of the premature mortality ("neopl") caused by neoplasms in 2009-2011. The explanatory factors in this regression model include settlement structure, health-impairing behaviour (smoking), number of non-profit 
organisations and difference between male and female life expectancy at birth. The negative sign of settlement structure indicates better mortality rates. Balatoni (2011) highlights the main correlations of higher health culture prevalent in more competitive urban regions and, among others, the beneficial health impacts of regional university centres. Dégi (2010) describes the correlations between psychosocial factors and age. The syndromes of depression, anxiety and despair become more pronounced with age. These are probably handled (directly and indirectly) in an efficient manner by non-profit organisations, and that is why their number can be a positive predictor in the model. Finally, the bigger the difference between male and female life expectancy at birth, the higher the SMR attributable to neoplasms. The indicator explains biological, lifestyle and social inequalities. Therefore it has a complex meaning here also: higher mortality attributable to neoplasms is caused by social differences and a lifestyle differing from that of women. Again, smoking plays a significant explanatory role.

Three factors are responsible for the spatial inequality of premature digestive system ("digest") mortality in men. Created by means of factor analysis, the latent development indicator appears as a protective factor. At macro level this is also referred to by Kovács $(2011)^{49}$. (Then) the model contains the mortality rate for chronic liver diseases and cirrhosis (caused by alcohol consumption), for/in South Transdanubia ${ }^{50}$. The former factor has positive signs (accounting for most of the digestive system mortality), while the latter spatial dummy indicates satisfactory conditions. The model is characterised by outstanding efficiency.

If the frequency of external causes of death ("external") is accepted as an indicator of the social establishment and its intensity, then this latter is properly indicated by the correlations. Mortality is explained by the micro-regional inequalities in terms of hidden economy, alcohol consumption, settlement structure and civil organisations. The first two indicators significantly increase male mortality related to external causes of death, while the aggregate indicator of settlement structure and the presence of a non-profit organisation decrease such mortality. Most micro-regions with higher mortality rates are found within the backward (external and internal) peripheries of Eastern Hungary, where lagging has become (rather) stable. Again, the micro-regions of BAZ county excel as a crisis area.

As far as the preventable causes of death ("preven") are concerned, mainly the microregional inequalities of lifestyle (smoking, male/female lifestyle difference) are evident.

\footnotetext{
49 When discussing the epidemiological transition, the author refers to a WHO publication (2008) where mortality caused by diseases of the digestive system is closely correlated (also) with national income.

${ }^{50}$ South Transdanubia is one of the crisis areas in terms of less favoured micro-regions in Hungary, yet the NUTS2 region is shown here, rather paradoxically, in a favourable setting..
} 
Hidden economy - as a proxy for socio-economic environment and lifestyle - increases mortality which could be prevented with adequate health awareness and health infrastructure. BAZ dummy is, again, a significant explanatory factor; the basic healthcare system needs further improvement in the micro-regions that show the highest values (Tokaji, Bodrogközi ${ }^{51}$ ) and particularly in the settlements with Roma population. In addition to lifestyle, this raises serious service supply problems in the preservation of health.

Table 4 Regression models of the main causes of death (male population, 2009-2011)

\begin{tabular}{|c|c|c|c|c|c|c|}
\hline & circul & neopl & digest & external & preven & respir \\
\hline constant & $\begin{array}{l}3.346^{* *} \\
(2.16)\end{array}$ & $\begin{array}{l}8.139^{*} \\
(3.54)\end{array}$ & $\begin{array}{l}1.216^{*} \\
(5.91)\end{array}$ & $\begin{array}{l}7.258^{*} \\
(7.01)\end{array}$ & $\begin{array}{l}3.118^{*} \\
(2.73)\end{array}$ & $\begin{array}{l}1.377^{*} \\
(3.24)\end{array}$ \\
\hline smoking & $\begin{array}{l}0.380^{*} \\
(7.24)\end{array}$ & $\begin{array}{l}0.336^{*} \\
(6.52)\end{array}$ & - & - & $\begin{array}{l}0.255^{*} \\
(6.26)\end{array}$ & $\begin{array}{l}0.060^{*} \\
(2.64)\end{array}$ \\
\hline criminal & $\begin{array}{c}0.013^{* * *} \\
(1.70)\end{array}$ & - & - & - & - & - \\
\hline hidden economy & $\begin{array}{c}13.242^{*} \\
(3.24)\end{array}$ & - & - & $\begin{array}{c}4.340^{* * *} \\
(1.68)\end{array}$ & $\begin{array}{l}8.286^{*} \\
(3.19)\end{array}$ & - \\
\hline doctors & $\begin{array}{c}0.598^{* *} \\
(2.30)\end{array}$ & - & - & - & - & - \\
\hline alcohol consumption & - & - & $\begin{array}{c}1.068^{*} \\
(31.06)\end{array}$ & $\begin{array}{c}0.163^{* * *} \\
(1.89)\end{array}$ & - & - \\
\hline development factor & - & - & $\begin{array}{c}-0.124^{* * *} \\
(-1.87)\end{array}$ & - & - & $\begin{array}{c}-0.403^{*} \\
(3.13) \\
\end{array}$ \\
\hline South Transdanubia (dummy) & - & - & $\begin{array}{c}-0.490^{* * * *} \\
(-2.41)\end{array}$ & - & - & - \\
\hline$B A Z$ (dummy) & $\begin{array}{c}1.780^{* * *} \\
(1.73)\end{array}$ & - & - & $\begin{array}{l}1.061^{* *} \\
(1.845)\end{array}$ & $\begin{array}{l}1.364^{* *} \\
(2.03)\end{array}$ & $\begin{array}{l}1.416^{*} \\
(3.19)\end{array}$ \\
\hline settlement structure & - & $\begin{array}{l}-0.735^{*} \\
(-3.56)\end{array}$ & - & $\begin{array}{l}-0.411^{*} \\
(-2.46)\end{array}$ & - & - \\
\hline nonprofit & - & $\begin{array}{c}-2.021^{* *} \\
(-2.01)\end{array}$ & - & $\begin{array}{l}-2.238^{*} \\
(-2.96)\end{array}$ & - & - \\
\hline diff_2010 & - & $\begin{array}{c}0.296^{* * *} \\
(1.65)\end{array}$ & - & - & $\begin{array}{l}0.480^{*} \\
(3.11)\end{array}$ & - \\
\hline lambda & $\begin{array}{l}0.476^{*} \\
(5.30) \\
\end{array}$ & - & $\begin{array}{l}0.278^{*} \\
(2.62) \\
\end{array}$ & $\begin{array}{c}0.211^{* *} \\
(1.91) \\
\end{array}$ & $\begin{array}{l}0.282^{*} \\
(2.66)\end{array}$ & $\begin{array}{l}0.515^{*} \\
(5.98) \\
\end{array}$ \\
\hline$W$ & - & $\begin{array}{c}0.199^{* * *} \\
(2.26)\end{array}$ & - & - & - & - \\
\hline pseudo $\mathrm{R}^{2}$ & 0.588 & 0.499 & 0.862 & 0.308 & 0.484 & 0.400 \\
\hline AIC & 844.5 & 808.0 & 387.7 & 691.3 & 743.9 & 538.7 \\
\hline Log likelihood & -416.2 & -398.0 & -189.9 & 339.7 & -366.9 & -265.3 \\
\hline $\mathrm{SC}$ & 863.5 & 826.9 & 400.4 & 710.3 & 759.7 & 551.3 \\
\hline LM lag (OLS) & $15.52^{*}$ & $4.21^{* *}$ & 0.00 & $6.45^{* *}$ & $4.28^{* *}$ & $15.09^{*}$ \\
\hline LM error (OLS) & $17.50^{*}$ & 1.56 & $5.19^{* *}$ & $3.03^{* * *}$ & $5.705^{* *}$ & $23.05^{*}$ \\
\hline
\end{tabular}

${ }^{*}$ At a significance level of $0.01,{ }^{* *}$ at a significance level of $0.05,{ }^{* * *}$ at a significance level of 0.10 . See z-score values in brackets. The spatial weights matrix is based on rook neighbourhood. Source: own computing and editing

\footnotetext{
${ }^{51}$ Both are classified among the most disadvantaged areas to be developed through multi-faceted adjustment programmes.
} 
As for the diseases of the respiratory system ("respir"), mortality has proved to follow the development gradient; the development factor works accordingly. Both the spatial inequality of smoking as a risk factor (KSH, 2009) and the crisis area (BAZ county) are significant predictors. The mortality rates in the micro-regions of Öriszentpéter, Szentgotthárd and Köszeg near the western border are in the worst one-sixth, just like the mortality rates in the micro-regions of Bodrogköz, Tokaj and Abaúj-Hegyköz ${ }^{52}$.

Although it has not been noted separately, spatiality plays a role - in addition to the BAZ county dummy and the South Transdanubia region dummy - in the explanation of the above causes of the death of men. Most models are SEM; however, SLM proved to be the right regression tool in the case of neoplasms.

\section{Results for female models}

Table 4 shows the regression estimation results. The regression of all premature mortality of Hungarian women ("all") results in a rather mixed model in comparison with that of men. In general, premature mortality is high in micro-regions with high mortality related to smoking and with below the average levels of development and health infrastructure. Again, BAZ county alone is an explanatory factor. Most micro-regions here (e.g. Bodrogköz, Tokaj and Mezőcsát ${ }^{53}$ ) are outliers, which confirms the crisis area hypothesis also for women. The joint appearance of development and hospital beds represents additional information; it may indicate the spatial inequalities of female health awareness in this model, reducing premature mortality rates.

The differences in the cardiovascular mortality of women ("circul") are attributable, at least in part, to the local features of poor health culture. Women living in more urbanised regions have higher chances to avoid premature mortality. Indirectly, this is the result of health infrastructure and health awareness. This is the first model to provide proof for ethnic and social segregation in the region: the cardiovascular mortality of women is higher where there is a high percentage of Roma people and endangered children. The BAZ dummy is, again, a significant explanatory factor, indicating that the region is hit by a complex spatial crisis.

The main contributors to the spatial differences of cancer-related mortality ("neopl") include the inequalities of health-impairing behaviour (smoking), lifestyle and infant

\footnotetext{
${ }^{52}$ The Abaúj-Hegyköz micro-region is (again) classified among the most disadvantaged areas to be developed through multi-faceted adjustment programmes in Borsod-Abaúj-Zemplén county.

${ }^{53}$ It's a most disadvantaged micro-region in Borsod-Abaúj-Zemplén county.
} 
mortality. The negative sign in the difference between male and female life expectancy is the variable of female lifestyle: the higher this indicator, the better the cancer-related premature mortality in women. The positive sign of infant mortality means that cancer-related mortality moves together with the condition of backwardness and the unavailability of health infrastructure. Except for the Pécs micro-region, all other micro-regions of Baranya county ${ }^{54}$ are considered a crisis area for neoplasms while Bács-Kiskun county ${ }^{55}$ performs better in this regard/field.

Table 4 Regression models of premature mortality in women ${ }^{56}$

\begin{tabular}{|c|c|c|c|c|c|c|c|}
\hline & all & circul & neopl & digest & external & preven & respir \\
\hline constant & $\begin{array}{l}18.071^{*} \\
(19.34)\end{array}$ & $\begin{array}{c}0.560^{*} \\
(20.15)\end{array}$ & $\begin{array}{l}9.174^{*} \\
(10.92)\end{array}$ & $\begin{array}{l}2.098^{*} \\
(38.68)\end{array}$ & $\begin{array}{c}1.05^{*} \\
(12.88)\end{array}$ & $\begin{array}{l}10.842^{*} \\
(11.08)\end{array}$ & $\begin{array}{l}1.865^{*} \\
(27.95)\end{array}$ \\
\hline development factor & $\begin{array}{l}-1.397^{*} \\
(-4.91)\end{array}$ & 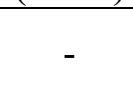 & - & - & - & $\begin{array}{l}-1.223^{*} \\
(-8.62)\end{array}$ & $\begin{array}{l}-0.072^{*} \\
(-3.73)\end{array}$ \\
\hline smoking & $\begin{array}{c}1.402^{*} \\
(10.43)\end{array}$ & $\begin{array}{l}0.029^{*} \\
(6.78)\end{array}$ & $\begin{array}{c}0.598^{*} \\
(10.00)\end{array}$ & - & - & $\begin{array}{l}0.271^{*} \\
(4.17)\end{array}$ & $\begin{array}{l}0.043^{*} \\
(4.36)\end{array}$ \\
\hline hospital bed & $\begin{array}{c}-0.083^{* *} \\
(3.20)\end{array}$ & - & - & - & - & - & - \\
\hline settlement structure & - & $\begin{array}{c}-0.030^{*} \\
(-3.65)\end{array}$ & - & - & $\begin{array}{c}0.079^{* * *} \\
(-1.74)\end{array}$ & - & - \\
\hline Roma & - & $\begin{array}{l}0.051^{* *} \\
(2.10)\end{array}$ & - & - & - & - & - \\
\hline endangered children & - & $\begin{array}{l}0.003^{*} \\
(2.78)\end{array}$ & - & - & - & - & - \\
\hline diff_2010 & - & - & $\begin{array}{l}-0.274^{*} \\
(-2.65)\end{array}$ & $\begin{array}{c}-0.013^{* *} \\
(-2.01)\end{array}$ & - & $\begin{array}{c}-0.509^{*} \\
(-4.94)\end{array}$ & - \\
\hline infant mortality & - & - & $\begin{array}{c}0.077^{* *} \\
(2.14)\end{array}$ & - & - & - & - \\
\hline alcohol consumption & - & - & - & $\begin{array}{c}0.186^{*} \\
(19.18)\end{array}$ & - & - & - \\
\hline criminal & - & - & - & $\begin{array}{c}0.004^{* * *} \\
(1.86)\end{array}$ & - & - & - \\
\hline suicide & - & - & - & - & $\begin{array}{c}1.031^{*} \\
(11.82)\end{array}$ & & - \\
\hline$B A Z$ (dummy) & $\begin{array}{l}3.283^{*} \\
(3.35)\end{array}$ & $\begin{array}{l}0.065^{* *} \\
(2.13)\end{array}$ & - & - & $\begin{array}{l}0.440^{*} \\
(2.69)\end{array}$ & - & - \\
\hline Baranya (dummy) & - & - & $\begin{array}{l}1.107^{*} \\
(2.08)\end{array}$ & - & - & - & - \\
\hline Bács_Kiskun (dummy) & - & - & $\begin{array}{c}-0.994^{* *} \\
(-1.99)\end{array}$ & - & - & - & - \\
\hline
\end{tabular}

\footnotetext{
${ }^{54}$ Baranya county makes part of the South Transdanubia region. The population of disadvantaged areas accounts for more than $50 \%$ of the county population; the county behaves accordingly in the regression equation.

${ }^{55} 70 \%$ of the micro-regions of this county located in the South Great Plain region are classified as less favoured areas, and the unfavourable socio-economic conditions affect some $50 \%$ of the county population. Nevertheless, the county's micro-regions are better positioned.

${ }^{56}$ In the models of circulatory, digestive and respiratory mortality we have used a logarithmic formula for the dependent variable in order to eliminate heteroscedasticity. Micro-regions with zero (0) SMR have been removed from the respiratory model.
} 
Table 4 (continued)

\begin{tabular}{|l|c|c|c|c|c|c|c|}
\hline & all & circul & neopl & digest & external & preven & respir \\
\hline Hajdu (dummy) & - & - & - & $\begin{array}{c}-0.091^{*} \\
(-2.73)\end{array}$ & - & - & - \\
\hline Fejer (dummy) & - & - & - & - & - & - & $\begin{array}{c}-0.192^{*} \\
(-2.80)\end{array}$ \\
\hline Veszprem (dummy) & - & - & - & - & - & - & $\begin{array}{c}-0.196^{*} \\
(-2.69)\end{array}$ \\
\hline Zala (dummy) & - & - & - & - & - & $-1.518^{*}$ & - \\
\hline MCN & 9.56 & 10.04 & 19.89 & 19.53 & 3.46 & 21.12 & 8.79 \\
\hline adj. R & 0.679 & 0.506 & 0.429 & 0.694 & 0.482 & 0.552 & 0.778 \\
\hline AIC & 865.5 & -306.0 & 640.0 & -313.0 & 319.1 & 607.8 & -46.92 \\
\hline Log likelihood & -427.68 & 159.0 & -314.0 & 161.5 & -155.5 & -298.9 & 29.46 \\
\hline Breusch-Pagan test & $13.33^{* *}$ & $10.64^{* *}$ & 1.63 & $24.18^{*}$ & 2.57 & $9.7^{*}$ & $17.31^{*}$ \\
\hline Jarque-Berra test & $14.98^{*}$ & $4.89^{* *}$ & $8.7^{* *}$ & $26.9^{*}$ & $122.4^{*}$ & 2.11 & 1.49 \\
\hline LM lag & 1.05 & 1.53 & 0.19 & 0.01 & 0.40 & 0.33 & 0.33 \\
\hline LM error & 0.06 & 1.96 & 0.42 & 0.06 & 0.50 & 0.57 & 1.47 \\
\hline Moran I (residual) & 0.012 & $0.06^{* * *}$ & -0.03 & 0.01 & -0.03 & 0.03 & 0.05 \\
\hline
\end{tabular}

${ }^{*}$ At a significance level of $0.01,{ }^{* *}$ at a significance level of $0.05,{ }^{* * *}$ at a significance level of 0.10 .

See t-score values in brackets. The spatial weights matrix is based on rook neighbourhood.

Source: own computing and editing

The digestive system mortality of women ("digest") is characterised mostly by spatial differences in lifestyle; it is evidenced by the indirect alcohol consumption indicator and by the difference in life expectancy. As the former one has positive sign, it can be stated - with reference to Józan (1997) - that excessive alcohol consumption is here also a problem. Again, women benefit from the difference in life expectancy because it is still a general protective factor despite the growing involvement of women in social and economic issues. The percentage of criminals (expression of social deviance) deteriorates the chances of preventing premature mortality due to this cause of death. The micro-regions with the lowest digestive system mortality rates are found in Hajdú-Bihar county, and this is why the county dummy is present also in the equation.

Again, the micro-region differences of the socio-economic gradient and smoking are prevalent for preventable ("preven") and diseases of the respiratory system ("respir"). In the former case the difference in life expectancy also appears, indicating again the benefits of health awareness in women and, under the control of the remaining factors, the micro-regions of Zala county are shown as a better positioned continuous area. Furthermore, two counties 
(Veszprém, Fejér ${ }^{57}$ ) in the Central Transdanubia region are also better positioned in terms of mortality caused by diseases of the respiratory system.

Unlike in the case of men, spatiality is not present as an explanatory or influencing factor in the explanation of premature mortality in women. All regression models are based on the ordinary least squares method.

\section{CONCLUSION}

This paper focuses on the spatial and socio-economic aspects of premature mortality, which is known as one of the major public health problems in Hungary. First, we wanted to see whether premature mortality can be characterised by clear spatial features (neighbourhood assimilation) in the micro-regions of Hungary. Second, we studied how premature mortality by gender and its main causes correlate with the level of socio-economic development, settlement structure, health behaviour, social capital, health infrastructure, segregation and spatiality.

Our autocorrelation analyses have confirmed that there is a substantial (although not outstanding) level of neighbourhood assimilation and regionalisation in the case of both men and women. Spatial clustering is highest for the causes of crude mortality, whereas no neighbourhood assimilation findings were identified for the causes of infectious and parasitic diseases. These correlations are more marked for the causes of death in the case of men. These findings adequately justify the use of spatial regression analysis.

In our opinion, the above socio-economic, settlement structure, spatiality, health awareness, social capital, health infrastructure, segregation and social deprivation play a major role in both male and female premature mortality and in the micro-regional inequalities of the main causes of death. In fact, there are great similarities in the roles of the factors involved in the explanation of the differences in both male and female premature mortality, and there are only slight differences between male and female models. It should be noted that, although - for the majority causes of death - men continue to react more sensitively to socioeconomic changes, women already show stronger regressions in several cases (external causes, preventable, respiratory system mortality). Nevertheless, neighbourhood relations are strictly gender-specific: contiguity is present in all male models but it is absent from all female models. It should be noted that, in addition to socio-economic and other explanatory

\footnotetext{
${ }^{57}$ It should be noted that there is no most disadvantaged micro-region in either of the two counties; in addition, the less favoured areas affect only a relatively small percentage of the county population. In fact, based on its per capita GDP, Middle Transdanubia is one of Hungary's most developed regions.
} 
factors, spatiality is very important with regard to the spatial inequalities of the various causes of death. According to our analyses, Borsod-Abaúj-Zemplén county (former heavy industry base) and some of its "outlier" micro-regions seem to have become particularly complex crisis areas in terms of premature mortality for both genders.

As far as the improvement of micro-regional health status is concerned, there is a big unused potential related, among others, to health awareness; in particular, a reduction in the level of smoking would be a major contributor to a drop in premature mortality rates. The role played by civil organisations should also be emphasized. Their higher presence in the region is coupled with lower premature mortality, which is evident mostly in the case of men. Whether they are involved in the propagation of health culture or in any other activities, these organisations play an outstanding role in the mitigation of psychosocial stress (invisible hand in mortality) affecting the entire country. Hungary may be able to improve its national health status through the development of its civil sphere.

In our opinion, future research work should focus on analyses at settlement level as it may give an additional impetus both to science and to regional health policy initiatives.

\section{REFERENCES}

Andorka, R. (2006). Bevezetés a szociológiába. [Introduction to sociology.] Budapest: Osiris. Anselin, L. (2005). Exploring Spatial Data with GeoDaTM : A Workbook. Spatial Analysis Laboratory Department of Geography University of Illinois. Illinois: Center for Spatially Integrated Social Science.

Bakos, I. (2003). Európai válságkezelési tanulmányok. [European crisis management studies.] Miskolc: EU Gazdaságtana Intézet.

Balatoni, I. (2011). Versenyképesség és egészségkultúra összefüggései regionális megközelítésben. Doktori értekezés. [The interrelations of competitiveness and health culture in regional context. $\mathrm{PhD}$ dissertation.] Debrecen: Debreceni Egyetem Kerpely Kálmán Növénytermesztési, Kertészeti és Regionális Tudományok Doktori Iskola.

Bálint, L. (2010). A területi halandósági különbségek Magyarországon 1980-2006. [Spatial mortality differences in Hungary, 1980-2006.] Budapest: Központi Statisztikai Hivatal Népességtudományi Kutató Intézet.

Black, D., Shore, E., Whitehead, M., Player, D., Turner, J., Fox, J., Morris, J., Townsend, P., Buller, A. (1980). Inequalities in health. The Black Report. London: Penguin Books.

Boncz, I., Sebestyén, A. (2006). Economy and mortality in Eastern and Western Europe between 1945 and 1990: the largest medical trial of history. International Journal of Epidemiology, 35, 796-797.

Borell, C., Arias, A. (1995). Socioeconomic factors and mortality in urban settings: the case of Barcelona, Spain. Journal of Epidemiology and Community Health, 49, 460-465.

Cornia, G. A., Paniccia, R. (2000). The Transition Mortality Crisis: Evidence, Interpretation and Policy Responses. New York: Oxford University Press.

Csite, A., Németh, N. (2007). A születéskor várható élettartam kistérségi egyenlőtlenségei az ezredforduló Magyarországán. [The micro-regional inequalities of life expectancy at 
birth in the Hungary of millenium.] Kormányzás Közpénzügyek Szabályozás, 2, 257 289.

Daróczi, E. (2004). Európa kelet-nyugati megosztottsága az életesélyek terén. [Europe's eastwest divide in terms of life expectancy.] In Daróczi E., Kovács K. (Ed.), Halálozási viszonyok az ezredfordulón: társadalmi és földrajzi választóvonalak. (pp. 11-40) Budapest: KSH-NKI.

Dégi, L. Cs. (2010). A daganatos betegségek pszichoszociális vetületeinek vizsgálata. Doktori értekezés. [The examination of pychosocial aspects of neoplasms. PhD dissertation.] Budapest: Semmelweis Egyetem, Mentális Egészségtudományok Doktori Iskola.

European Commission (2008). Together for health: A strategic approach for the EU 20082013. Press release. Retrieved December 12, 2010, from http://www.europarl.europa.eu/sides/getDoc.do?pubRef=-//EP//TEXT+IMPRESS+20081009IPR39072+0+DOC+XML+V0//EN

Fiscella, F., Franks, P. (1997). Poverty or income inequality as predictor of mortality: longitudinal cohort study. British Medical Journal, 314, 1724-1728.

Groenewegen, P. P., Westert, G. P., Boshuizen, H. C. (2003). Regional differences in Healthy Life Expectancy in the Netherlands. Public Health, 117, 424-429.

Gutiérrez-Fisac, J. L., Gispert, R., Sola, J. (2000). Factors explaining the geographical differences in Disability Free Life Expectancy in Spain. Journal of Epidemiology and Community Health, 54, 451-455.

Hablicsek, L., Kovács K. (2007). Az életkilátások differenciálódása iskolázottság szerint, 1986-2005. [Differentiation of life expectancy by educational attainment, 1986-2005.] Budapest: KSH.

Józan, P. (1997). A nők egészségi állapotának néhány jellemzője. [Some features of women's health situation.] In Lévai, K., Tóth, I. Gy. (Ed.), Szerepváltozások: Jelentés a nők és férfiak helyzetéről 1997 (pp.107-121). Budapest: Tárki-Munkaügyi és Egyenlő Esélyek Titkársága.

Klinger, A. (2006). Újabb adatok a vidéki kistérségek és a budapesti kerületek halandósági különbségeiröl. [Recent data on mortality of rural microregions and Budapest districts.] Demográfia, 49, 197-231.

Kopp, M. S., Skrabski, A., Székely, A., Stauder, A., Williams, R. (2007). Chronic stress and social changes, socioeconomic determination of chronic stress. Annals of the New York Academy of Sciences, 325-338.

Kopp, M. S., Skrabski, Á. (2001). Pszichoszociális tényezők és egészségi állapot. [Psychosocial factors and health status.] A Népesedéspolitikai ad-hoc Munkabizottság számára készített tanulmány. Budapest: Research Paper.

Kovács, K. (2011). Társadalmi egyenlőtlenségek a mortalitásban Magyarországon (19712008) és az epidemiológiai átmenet elmélete. [Social inequalities in hungarian mortality (1971-2008) and the theory of epidemiological transition.] Budapest: KSH-NKI.

Központi Statisztikai Hivatal (2007): Tájékoztató a kiemelten támogatott kistérségekről. [Information on the priority support micro-regions.] Budapest: Központi Statisztikai Hivatal.

Központi Statisztikai Hivatal (2009). A légzőszervi megbetegedések. [Respiratory diseases.] Statisztikai tükör, 44, 1-3.

Lackó, M., Semjén, A., Fazekas, M., Tóth, I. J. (2011). Rejtett gazdaság, rejtett foglalkoztatottság - kutatási eredmények és kormányzati politika a nemzetközi és hazai irodalom tükrében. [Hidden economy, underground employment - research results and government policy in the light of international and domestic literature.] Budapest: Research Paper. 
Leyland, A. H. (2004). Increasing Inequalities in Premature Mortality in Great Britain. Journal of Epidemiology and Community Health, 58, 296-302.

Mackenbach, J., Looman, C.W. (1994). Living standards and mortality in the European Community. Journal of Epidemiology and Community Health, 48, 140-145.

Mackenbach, J. P. (2006). Health Inequalities: Europe in Profile. Rotterdam: Erasmus MC University Medical Center.

Mackenbach, J. P., Kunst, A. E., Looman, C. W. (1991). Cultural and economic determinants of geographical mortality patterns in the Netherlands. Journal of Epidemiology and Community Health, 45, 231-237.

Marmot, M. (2004). Status Syndrome. London: Bloomsbury Publishing.

Meslé, F. (2004). Mortality in Central and Eastern Europe: long-term trends and recent upturns. Demographic research. Research Paper, Special Collection 2.

Nemes Nagy, J. (2009). Terek, helyek, régiók. - A regionális tudomány alapjai. [Spaces, places, regions. - Bases of regional science.] Budapest: Akadémia Kiadó.

Omran, A. (1971). The Epidemiologic Transition. A Theory of the Epidemiology of Population Change. The Milbank Memorial Fund Quarterly, 49, 509-538.

Preston, S. H. (1975). The changing relation between mortality and level of economic development. Reprinted International Journal of Epidemiology (2007), 36, 484-490.

Queste, A., Fehr, R., Kistemann, T., Blettner, M. (2002). Geo-socio-economic factors as determinants of health: An analysis of small area mortality rates in Germany. Geo Health Conference, Victoria University of Wellington.

Skrabski, Á. (2003). A társadalmi tőke és a középkorú halálozás összefüggései. [The relations of social capital and middle-ageds' mortality.] Demográfia, 46, 95-103.

Szilágyi, D., Uzzoli, A. (2013). Az egészségegyenlőtlenségek területi alakulása az 1990 utáni válságok idején Magyarországon. [The spatial evolution of health inequalities in Hungary during the post-1990 crises.] Területi Statisztika, 53, 130-147.

Tóth, G. (2003). Területi autokorrelációs vizsgálat a Local.Moran I módszerével. [Spatial autocorrelation test with the Local Moran I method.] Tér és társadalom, 17, 39-49.

Uzzoli, A. (2008). The mortality situation and its spatial dimension in Hungary. Regionální studia czech regional studies, 2, 41-50.

Uzzoli, A. (2013). A válság és egészség Magyarországon - Feltételezések és vélemények. [The crisis and health in Hungary - Assumptions and opinions.] Egészségtudomány, 57, $10-27$.

Vitrai, J. (2011). Az egészség és az egészségegyenlőtlenség egyéni és közösségi befolyásoló tényezöi. Doktori értekezés. [The individual and community factors that influence health and health inequalities. PhD dissertation.] Pécs: Pécsi Tudományegyetem Egészségtudományi Kar, Egészségtudományi Doktori Iskola.

Weidner, G., Cain, V. (2003). The Gender Gap in Heart Disease: Lessons From Eastern Europe. American Journal of Public Health, 93, 768-770.

Whitehead, M. (1997). Life and death over the millenium. In Drever, F., Whitehead, M. (Ed.), Health Inequalities (pp. 7-28.) London: Stationery Office.

WHO (2008). The World Health Report. Primary Health Care Now. More than ever. Geneva: WHO Press.

Wilkinson, R., Marmot, M. (2003). Social determinants of health: the solid facts. Copenhagen: WHO Press.

Woods, L. M., Rachet, B., Riga, M., Stone, N., Shah, A., Coleman, P. M. (2005).

Geographical variation in life expectancy at birth in England and Wales is largely explained

by deprivation. Journal of Epidemiology and Community Health, 59, 115-120. 